\title{
RELATIONSHIP BETWEEN CUSTOMER SATISFACTION AND SERVICE QUALITY IN PRIVATE BANKS OF INDIA
}

\author{
ABSTRACT \\ This study attempts to analyze the extent of service quality and \\ customer loyalty in private banks. For any bank to grow and develop \\ sustainably, they need to ensure their customer's satisfaction in which \\ service quality plays a decisive role. Satisfied customers, similarly, \\ provoke customer's loyalty towards their banks that can then enhance \\ the profitability of Banks. With the help of the SERVQUAL Model, \\ the study also traces various factors considered when measuring \\ customer satisfaction. The primary data were collected with the help \\ of a standardized questionnaire on the said topic, which conveniently \\ collected a sample of 200 respondents accessing private banking \\ services in different cities of India. The collected data are analyzed \\ with the statistical tools of Factor Analysis, Reliability, and Validity \\ tests with the help of SPSS. \\ Key Words: Digital banking, Service quality, Responsiveness, Customer \\ satisfaction, Customer loyalty

\section{Shubhangi Mishra} \\ Bharati Vidyapeeth Institute of Management and Entrepreneurship Development \\ Bharati Jadhav \\ Bharati Vidyapeeth Institute of Management and Entrepreneurship Development \\ Correspondence: \\ Address: 411, Govindam Gopalam Apartment, Tirupati Colony, Lalaram Nagar \\ near St. Paul School, Indore, MP (452018) \\ E-mail:mishra.shubhangi21@gmail,com
}




\section{INTRODUCTION}

The nature of the development of the banking system in India was evolutionary. A bank performs several functions, offers different products and services depending on the customer's needs and requirements. Hence, its multitude of functions cannot be encapsulated into a single definition. The origin of the word 'bank' is traced back to the German word 'banck' which means heap or mound or joint-stock fund. The Italian word 'banco' was derived from this to mean a heap of money.

A bank is commonly understood as an institution that accepts money in terms of deposits and then lends it to other customers to make profits. It plays a vital role in maintaining the economic stability of a country. The major function of a bank includes the management of idle funds; it accepts idle funds from customers in the form of deposits and then makes the same available to others to make investments. This maintains the cash cycle in the economy and bridges the gap between savers and borrowers. In current days, when there is cut-throat competition in the banking industry and there is so little to compete as several players are offering homogeneous products and services, delivering a great customer experience remains one of the crucial ways for banks to stand out. Service quality is the strategic tool to reinforce competitive advantages and increase profitability, hence, banks put in lots of efforts providing quality service to retain their existing customers and also to consolidate and increase their customer base (Tam, 2004). Apart from ensuring the trust of customers, banks must also focus on providing advanced techno-friendly services for easy access and instant delivery of products or services (John, 2017).

Although modern-day banking has become more user-friendly, all the banking services and products are customized as per the customer's demand. Therefore, banks nowadays are focused to create customers value for their business. This crucial shift to value creation is nothing but the result of fierce competition in the banking sector and also the outcomes of globalization, privatization, and liberalization (Priyanath and Anjalika, 2018). Modern-day banking is entirely dependent on technology which promotes paperless banking operation and sustainable development. Such innovations have made the customer transaction seamlessly convenient and dynamic (Bakhtiar and Waqarul, 2012). In the past few years, we can see that the Indian banking system is not limited to urban and metropolitan cities anymore as they have now extended their reachability to every corner of the country. This has only become possible because of the innovations and constant technological advancements. In earlier days, customers had to travel for the banking services 
but today we can see an impeccable development of the banks, which now have extended their service areas to every small village and un/under-developed areas. Advancements such as electronic fund transfers, clearing systems, cheque truncations, and other assistant techniques in the banking, financial services and insurance (BFSI) industry have made the bank employee's work easier; it also ensures convenience and safety to the customer. Along with it, new initiatives in the field such as banking representatives and bank kiosks have also taken place in recent times which are proved to be beneficial for both customers and banks. It saves the customer's time and has made everything available on the doorstep; for the banks, it is the best way of enhancing their reachability and expands their customer base (Mishra and Sahoo, 2010). While analyzing the customer satisfaction in the study, the parameters in terms of branch banking, the digital banking segment namely; internet banking and mobile banking were also taken into consideration.

This study of the relationship between customer satisfaction and service quality in private banks of India was proposed to identify the various determinants of customer satisfaction in private banks and its relationship with the service quality offered by them. The study provides observed evidence as regards various factors which are associated with customer satisfaction in banks as well as the other possible strategies that can be adopted and implemented by the banks to enhance their banking experience. All these findings will facilitate further policy-making of private banks which will facilitate them to survive and sustain in the growing competitive environment without compromising with their customers' satisfaction. The study will provide a comprehensive framework for service quality dimensions concerning customer satisfaction and customer loyalty. The purpose of this study is to analyze the satisfaction level of the customer towards the services provided by the various private banks in India. The research addresses the customer's opinions on banking services which will provide helpful guidance for further development and growth of the banking industry. This research focuses on the level of customer satisfaction on banking services of private banks in various cities of India. The study is guided by the following specific objectives:

- To study service quality in private banks of India.

- To study customer satisfaction in private banks of India from a customer's perspective.

- To study the relationship between service quality and customers satisfaction in private banks. 
- To study the relationship between service quality and customer's loyalty in private banks.

- To establish strategies and provide suggestions to enhance customer satisfaction in private banks based on the findings of the study.

\section{Research questions}

a. What is the relationship between the level of customer satisfaction and the service of the private banks?

b. What is the relationship between level the customer's loyalty and customers satisfaction in private banks?

\section{Research hypotheses}

For banks to sustain and achieve long-term growth and profits and growing economic returns, retentions of valuable customers act as a base pillar (Yeung, Ging, Sschumann, Gardial, and Bums, 1991). Customers prefer to continue their association with those banks which provide good service quality. And a satisfied customer generally connects with a single and trustworthy bank which becomes the single-stop for all the products or services (Sureshchandar, Rajendran, and Ananthraman, 2003). That is how a satisfied customer becomes a loyal customer. Retention of customers is so economical than acquiring new customers that banks prominently focus on enhancing the product or service experience for their customers, frequent feedbacks, customer relationship management, deals and offers, quick and hassle-free services, phone banking, Etc. By keeping these points in find, the following hypotheses are developed:

Hypothesis 1

$H_{0}$ : There is a significant relationship between customer satisfaction and service quality of private banks $H_{1}$ : There is no significant relationship between customer satisfaction and service quality of private banks Hypothesis 2

$H_{0}$ : There is a significant relationship between customer satisfaction and the customer's loyalty towards their banks.

$H_{1}$ : There is no significant relationship between customer satisfaction and the customer's loyalty towards their banks.

\section{LITERATURE REVIEW}


The objectives of (Srinivas and Rao, 2018) study is to discover the perceptions of customers regarding the quality of service delivered by public and private banks, to determine the relevant dimensions of service quality for the banking sector, and to identify the dimensions of SERVQUAL that ensures the maximum satisfaction for customers in the banking sector. The study explores the service quality of the public banks in the Warangal district of Telangana. The dissatisfied customers find responsiveness and empathy dimensions as the twin concept lacked by the bank. So far as the satisfied customers are concerned, there exists a long gap between the expected service quality (what exact types of services the customers expect from the bank) and actual service quality (what services are getting from a bank in the real sense).

The study of Hennayake (2017) evaluates the relationship between service quality and perceived customer satisfaction, identifies the impact of human-related service quality factors on customer satisfaction in the commercial banking sector, and proposes recommendations to enhance perceived customer satisfaction in the banking industry. The finding highlights that the human-related factors of perceived service quality have a greater impact on customer satisfaction whereas reliability and responsiveness are the most influential factors on customer satisfaction. In order to stand out in today's competitive banking industry, there is a need for banks to build customer relationships instead of just offering the products or services; building customer relationships means delivering superior value over competitors to the target customers, this helps in retaining existing new customers and attracting potential customers. Since higher levels of quality lead to higher levels of customer satisfaction, any organisation, which provides a quality product or service, must consider their customer's feedback and satisfaction after availing of the service or using the product.

\section{Key concepts}

The study of the relationship between customer satisfaction and service quality of private banks in India requires a clear understanding of some primary concepts. This section of the paper hence introduces the readers to some basic comprehension of the key concepts in the study.

\section{Customer satisfaction}


Customer satisfaction refers to an attitude or evaluation of a customer comparing their actual experiences and pre-purchase expectations. customer satisfaction is a fundamental determinant of long-term consumer behavior. (Mishra and Sahoo, 2010). Delivering customer satisfaction, which is a post-purchase judgment, is at the heart of modern marketing. Customer satisfaction is the valued outcome of good business practice. According to Drucker, the principal purpose of business is to create satisfied customers. It is an individual's perception of the performance of products or services about to the expectations (Schiffman and Kanuk, 2004).

\section{Service quality}

Kumar and Manjunath (2012) defined service quality as the difference between customers' expectations of service and their perceptions of the actual service performance. Service quality is the core concept for ensuring a successful supply of services in general. Private banking involves insubstantial goods requiring the participation of customers in the process (Munusamy and Shankar, 2010). In such a setting, bank services aim to optimize the service quality to attain a superior outcome level. The outcome of service quality, what firms expand by delivering a high-quality service, is the return on a concept of quality and service profit chain.

\section{Customer loyalty}

Customer loyalty can lower costs and increase the profitability of any organization. The cost of retaining a customer is relatively cheaper compared to that of attracting a new customer (Lam and Burton, 2006). In simple words, customer loyalty is generally what a customer reveals to a particular brand and the likeliness of being associated in the future (Uncles, Dowling, and Hammond, 2003). The loyalty of customers is a behavioral aspect, which differs from person to person depending on their perception. For some customers, the priority may be the quality of the service while the availability of services for others. It simply means the customer's likeliness to carry out different operations with the same bank repeatedly.

\section{Variables of the study}

The SERVQUAL model is majorly used as a multi-dimensional research instrument used to measure the service quality experienced by customers and their level of satisfaction 
(Parasuraman, Zeithaml, and Berry, 1985). In addition to this, another dimension is added to this model in this study, which is customer loyalty.

a. Empathy: Empathy is understood as a source of conveying feelings of caring, which makes the customer feel unique and special. It often shows that the banks are paying close attention to their customers while offering them products or rendering services. Prioritizing the customer in the bank is the core of empathy. The study has used security, credibility, and accessibility to avail services to measure empathy.

b. Assurance: Assurance has been defined as the attitude and behavior of the employees as well as the staff's ability to provide a courteous, cooperative, friendly, and competent service environment to the customers. It means that the employees can tackle the queries with their knowledge and capacity to transfer confidence as well as trust to the customers by keeping them informed and listening to them, regardless of certain barriers like native language, educational level, age, etc.

c. Reliability: Reliability simply means being trustworthy and honest in consistently performing the actions. Reliability defines the customer's perception with regards to the reclamation of the bank's commitment to rendering the service sincerely, timely, and satisfactorily. It shows that the bank strives to provide services correctly and are being responsible for the results of its actions.

d. Tangible attributes: Tangibles refer to the physical image, features, and facilities that the customers can access in a bank branch. Privileges such as speed and efficiency of transactions, availability and proper working of equipment, counters in the branch, opening hours, the appearance of the branch are considered as tangibles for measuring tangible attributes.

e. Responsiveness: Responsiveness is one of the major reasons why customers switch to other banks. It refers to customer's perception of the bank's activities and the willingness of employees to respond to customer's requests. The study has used rendering instant services, making prompt decisions, quickness in attending problems, and speedy grievance redress as a measure of responsiveness.

f. Loyalty: Customer loyalty can be understood as their likeliness to carry out different operations at the same bank. It is the potential of the relationship between the bank and the customer. Loyalty heavily depends on the behavior and attitude of the customer, the study has used availing all services from the same 
bank, recommending their bank to others, and sharing banking relations with one or banks as the variables to measure the customer's loyalty.

\section{RESEARCH METHODOLOGY}

This section of the study explains the methodology of research to answer research questions and to justify the research objectives. Further after addressing these questions, the hypotheses of the study have been developed. Next, a sampling frame and a systematic data collection procedure have been talked through.

The research model is developed to determine the interrelationship between the service quality attributes, customer satisfaction, and customer loyalty in the private banks in India. This research model is illustrated in Figure1 (Research model).

Figure 1. Research model

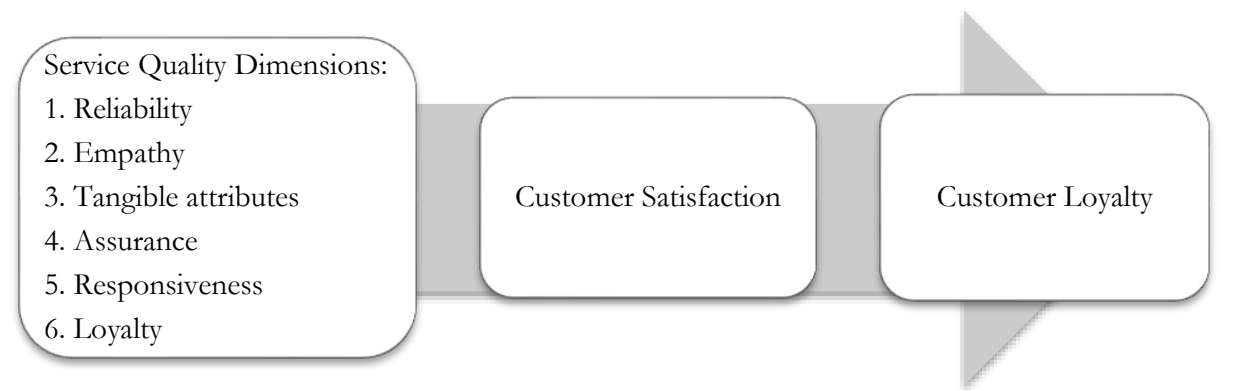

Data collection and empirical context refer to the overall strategy that you choose to integrate the different components of the study incoherently and logically, thereby, ensuring you will effectively address the research objectives, it constitutes the blueprint for the collection, measurement, and analysis of data. The various types of research design layouts are illustrated in Figure 2 (Research design and data collection). The descriptive research was carried out to evaluate the service quality, customer satisfaction, and customer loyalty in private banks of India. Hence, the researcher initially started by searching previous knowledge of the field. This former knowledge is used to identify various dependent and independent variables. The population of a study refers to a specific group of the units such 
as individuals, households, organizations, and similar that are targeted for a definite study. For the study, 200 customers of the private bank of different cities in India were identified.

Figure 2. Research design and data collection

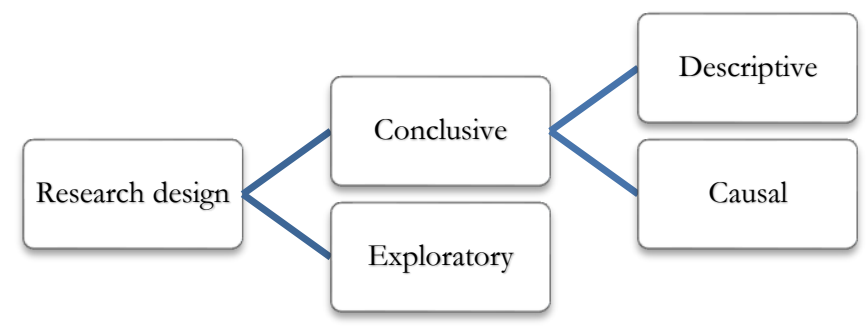

The non-Probability sampling method was used for collecting data for this study. Under this sampling procedure, a convenience sampling procedure was adopted for this research. The sample size of the study as per the researcher's convenience is 200 respondents. The primary data is collected through the questionnaire method. The respondents are asked to give their opinion relating to the various service quality of the private banks. The first part of the questionnaire comprises demographic variables with optional questions and the second part comprises service quality dimensions.

After collecting the data, questionnaires were checked for completeness. By using SPSS software, at first, variables were developed and data were entered accordingly. For this research multivariate statistical analysis was used. The Likert scale was used for rating responses. Each testimonial is measured by 5 - point Likert scale: $1=$ Strongly disagree; 2=Disagree; $3=$ Neutral; $4=$ Agree; $5=$ Strongly agree. Similarly, dependent and independent variables were measured by focusing on Cronbach's alpha (must be above $60 \%$ ). By using the software program, SPSS, the correlation between service quality dimensions that influence customer satisfaction and loyalty in private banks and the linear regression, and the analysis were done. Customer satisfaction played a role of a mediating variable and customer loyalty is considered to be a dependent variable. Factor and reliability analysis and hypothesis testing are also used to find out the results.

\section{DEMOGRAPHIC PROFILE OF THE RESPONDENTS}




\section{Age distribution}

The age distribution of the respondents is illustrated in Table 1 . We can see that the majority of respondents, $66 \%$ belong to the very first category of below 25 years. This implies that a lot of youngsters belonging to this generation are potential customers of the banks and are using their products and services regularly. The respondents belonging to other categories are given as follows:

Table 1. Age distribution of the respondents

\begin{tabular}{ccc}
\hline Age Groups & No. of Respondents & $\%$ of Total \\
\hline Below 25 years & 132 & 66.00 \\
$25-35$ years & 27 & 13.50 \\
$36-45$ years & 21 & 10.50 \\
$46-55$ years & 15 & 7.50 \\
55 years and above & 5 & 2.50 \\
Total & 200 & 100 \\
\hline
\end{tabular}

\section{Gender composition}

The gender composition of the respondents was $45.50 \%$ female and $54.50 \%$ male. This shows that even females are empowered enough to independently avail the banking services. It also eliminates the stereotypes that a whole family would rely on a single (family) account, frequently with a name of a male in the family. Contrary to this, nowadays people even started to open their children's accounts when they are minors, just a habit of saving for their children's future. The study also shows that these respondents are associated with various banks to avail different services and products, whereas some customers stick to their single bank for everything.

\section{Educational qualification}

Talking about the highest educational qualifications of the respondents, the majority of the respondents $48 \%$ belongs to the post graduate category. Literacy plays a vital role in developing one's personality, an educated individual is more likely to avail the banking services and products. Although the banking staff of every bank helps their customers in all possible manners, even when it comes to a simple task like assisting their customers in form filling etc., the academic qualifications of service users are often associated with the frequency of using bank services. The respondents categorized as per their highest educational qualification are given in Table 2 Table 2. 
RELATIONSHIP BETWEEN CUSTOMER SATISFACTION AND SERVICE QUALITY IN PRIVATE BANKS OF INDIA

Table 2. Educational qualification of the respondents

\begin{tabular}{ccc}
\hline Educational Qualification & No. of Respondents & \% of Total \\
\hline HSC/SSC & 15 & 7.00 \\
Under graduate & 25 & 12.50 \\
Graduate & 96 & 48.00 \\
Post graduate & 2 & 1.00 \\
Diploma & 14 & 7.00 \\
Professional & 48 & 24.00 \\
Total & 200 & 100 \\
\hline
\end{tabular}

\section{Respondent's location}

The distribution of the 200 respondents as per the location is given in Table 3. The majority of the respondents $52.50 \%$ were from Indore and 11\% were from Mumbai.

\section{Employment status (occupation)}

Considering the employment status of the respondents given in Figure 3, it shows that 32.50\% are salaried and working in the private sector, $53.50 \%$ are students and are currently not working and $6.50 \%$ are self-employed.

\section{Area of residence}

The area of residence plays a vital role when it comes to bank branches. Earlier there was not a well-developed network of bank branches in rural areas, although, now banking channels and networks have spread to every corner of the country. When it comes to questions about the area of residence of the respondents, $79.50 \%$ of them stated that they live in the urban area, while $15.50 \%$ said they live in the semi-urban area and the remaining $5 \%$ in the rural area.

\section{Marital status}

Talking about the marital status of the respondents, $72.50 \%$ said they were unmarried, $26 \%$ were married and the rest $1.50 \%$ belong to the others category. 
Table 3. Location of the respondents

\begin{tabular}{cccccc}
\hline Cities & $\begin{array}{c}\text { No. of respon- } \\
\text { dents }\end{array}$ & $\begin{array}{c}\% \\
\text { of Total }\end{array}$ & Cities & $\begin{array}{c}\text { No. of respon- } \\
\text { dents }\end{array}$ & $\begin{array}{c}\% \\
\text { of Total }\end{array}$ \\
\hline Agra & 1 & 0.50 & Mathura & 1 & 0.50 \\
Ahmedabad & 1 & 0.50 & Mhow & 2 & 1.00 \\
Ajmer & 1 & 0.50 & Mumbai & 22 & 11.00 \\
Aurangabad & 1 & 0.50 & Nagda & 1 & 0.50 \\
Barwani & 1 & 0.50 & Nagpur & 3 & 1.50 \\
Bhandara & 1 & 0.50 & Nashik & 1 & 0.50 \\
Bharatpur & 1 & 0.50 & Nellore & 2 & 1.00 \\
Bhilwara & 1 & 0.50 & Palia Kalan & 1 & 0.50 \\
Bhopal & 5 & 2.50 & Pune & 6 & 3.00 \\
Bhubaneswar & 1 & 0.50 & Raipur & 1 & 0.50 \\
Damanjodi & 1 & 0.50 & Ranchi & 3 & 1.50 \\
Delhi & 1 & 0.50 & Rohtak & 1 & 0.50 \\
Dhanbad & 1 & 0.50 & Siliguri & 1 & 0.50 \\
Faridabad & 1 & 0.50 & Sonbhadra & 3 & 1.50 \\
Ghaziabad & 1 & 0.50 & Surat & 3 & 1.50 \\
Howrah & 1 & 0.50 & Trivandrum & 1 & 0.50 \\
Indore & 105 & 52.50 & Udaipur & 1 & 0.50 \\
Jabalpur & 1 & 0.50 & Ujiain & 1 & 0.50 \\
Jaipur & 9 & 4.50 & Vaibhav wadi & 1 & 0.50 \\
Jaunpur & 1 & 0.50 & Varanasi & 2 & 1.00 \\
Kolkata & 3 & 1.50 & Veraval & 1 & 0.50 \\
Lucknow & 3 & 1.50 & Total & 200 & 100 \\
\hline
\end{tabular}

Figure 3. Employment status of the respondents

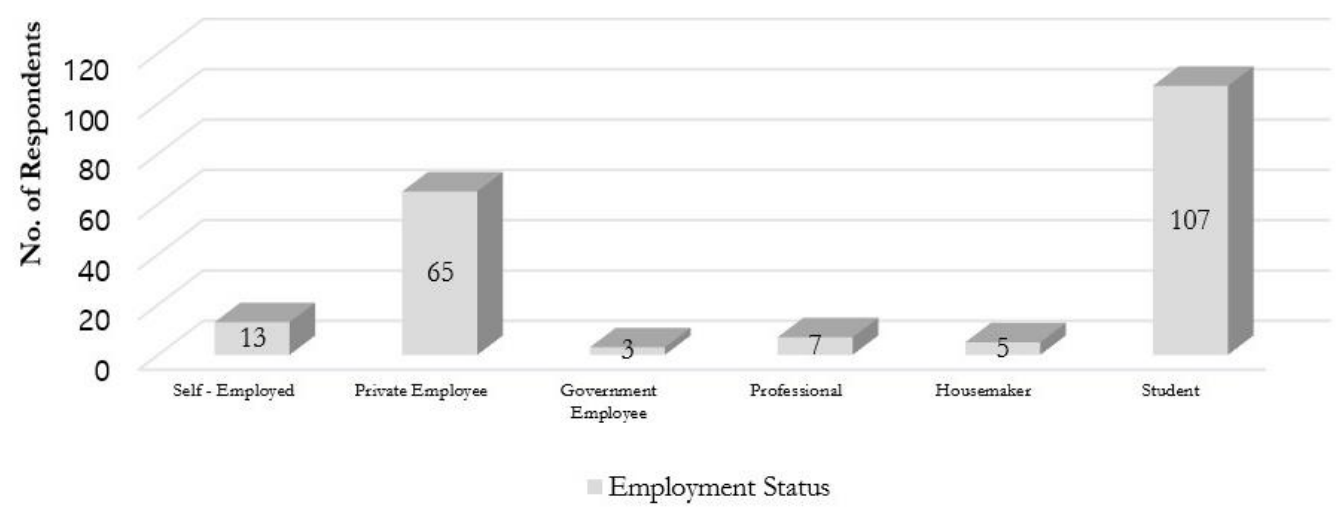

\section{Monthly income}

Figure 4 indicates the respondent's monthly income, wherein $20.50 \%$ have a monthly income between Rs. 15,000 - Rs. 30,000, the other 10.50\% have monthly income above Rs. 
60,000 and $45 \%$ have said that they are not currently earning (as a majority of them are students).

Figure 4. Monthly income of the respondents

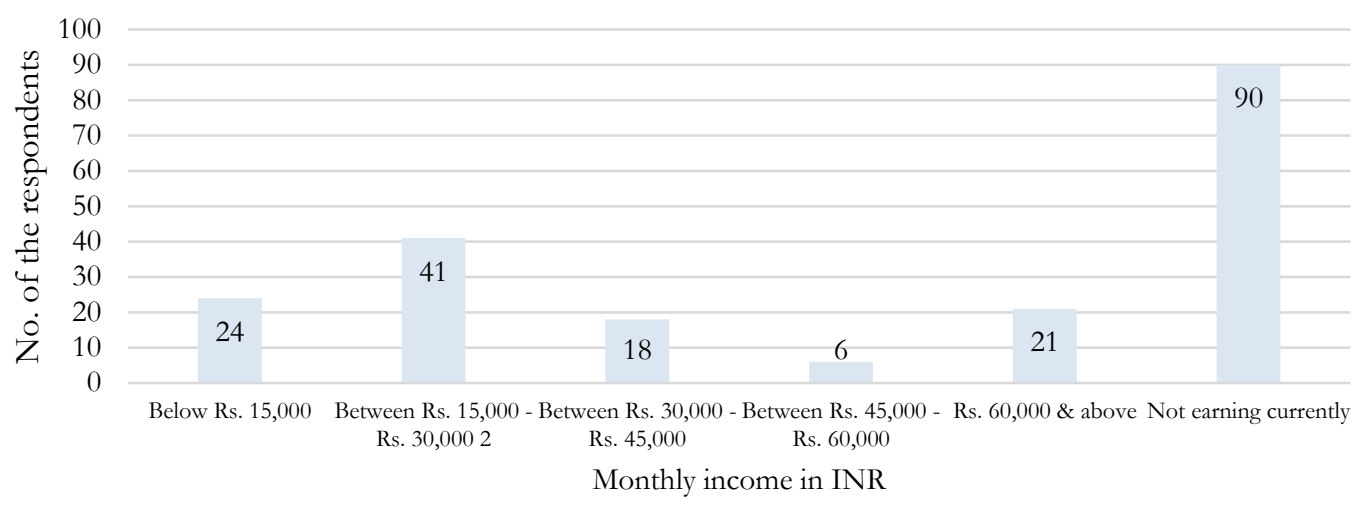

\section{FINDINGS}

\section{Descriptive statistics}

To begin with the data analysis and interpretation of the responses, firstly we have performed the descriptive statistics of the study. It helps to summaries and define the characteristics of the huge numbers of data which aims to describe the data's condition. Table 4 (descriptive statistics) shows the minimum and maximum statistic value of all the demographic questions, it also shows the mean statistic, standard deviation statistic and the skewness of all the line items. 
Table 4. Descriptive statistic

\begin{tabular}{|c|c|c|c|c|c|c|c|c|}
\hline & \multirow{2}{*}{$\mathbf{N}$} & \multirow{2}{*}{ Minimum } & \multirow{2}{*}{ Maximum } & \multirow{2}{*}{ Mean } & \multirow{2}{*}{$\begin{array}{c}\text { St. } \\
\text { deviation }\end{array}$} & \multirow{2}{*}{ Variance } & \multicolumn{2}{|c|}{ Skewness } \\
\hline & & & & & & & Statistics & $\begin{array}{l}\text { Std. } \\
\text { error }\end{array}$ \\
\hline Gender & 200 & 1.00 & 2.00 & 1.45 & 0.44 & 0.24 & 0.18 & 0.17 \\
\hline $\begin{array}{c}\text { Age } \\
\text { distribution }\end{array}$ & 200 & 1.00 & 5.00 & 1.67 & 1.09 & 1.18 & 1.51 & 0.17 \\
\hline $\begin{array}{c}\text { Marital } \\
\text { status }\end{array}$ & 200 & 1.00 & 3.00 & 1.28 & 0.47 & 0.22 & 1.24 & 0.17 \\
\hline $\begin{array}{l}\text { Educational } \\
\text { qualification }\end{array}$ & 200 & 1.00 & 6.00 & 3.32 & 1.26 & 1.59 & 0.02 & 0.17 \\
\hline $\begin{array}{l}\text { Employment } \\
\text { sattus }\end{array}$ & 200 & 1.00 & 6.00 & 4.23 & 2.00 & 4.03 & -0.39 & 0.17 \\
\hline $\begin{array}{l}\text { Monthly } \\
\text { income }\end{array}$ & 200 & 1.00 & .00 & 4.14 & 1.97 & 3.89 & -0.39 & 0.17 \\
\hline $\begin{array}{l}\text { Area of } \\
\text { residence }\end{array}$ & 200 & 1.00 & 3.00 & 2.74 & 0.53 & 0.29 & 2.04 & 0.17 \\
\hline $\begin{array}{l}\text { Years of } \\
\text { association } \\
\text { with the } \\
\text { bank }\end{array}$ & 200 & 1.00 & 4.00 & 2.32 & 1.15 & 1.32 & 0.27 & 0.17 \\
\hline $\begin{array}{l}\text { Valid N } \\
\text { (listwise) }\end{array}$ & 200 & 1.00 & & & & & & \\
\hline
\end{tabular}

Note: All the responses are valid i.e., 200, since there are no missing data in the frequency table.

\section{Reliability}

The reliability analysis helps to determine the extent to which a scale produces compatible and consistent results. Here, with the help of Cronbach's alpha, we have determined the reliability of the variables on SPSS. As shown in Table 5 (reliability statistics) the Cronbach's alpha of the study is 0.870 . The generally accepted range is $0.6-0.7$, whereas 0.8 and the greater value represents a very good level of internal consistency i.e., items are closely related as a group.

Table 5. Reliability statistics

\begin{tabular}{rrr}
\hline Cronbach ' s alpha & Cronbach ' s alpha based on standardized items & Number of items \\
\hline 0.870 & 0.872 & 9 \\
\hline
\end{tabular}




\section{Factor analysis KMO and Total variance}

The Kaiser - Meyer - Olkin measure of sampling adequacy measures the proportion of variance in the variables of the study. It varies between 0 to 1 , and any value closer to 1 is better, wherein a value of at least 0.6 is a suggested minimum. According to Table 6 (KMO and Bartlett's test), the value is 0.836 which is very much suitable.

Table 6. KMO and Bartlett's Test

\begin{tabular}{lr}
\hline Kaiser- Meyer- Olkin measure of sampling adequacy & $\mathbf{0 . 8 3 6}$ \\
Bartlett's test of sphericity approx. Chi-Square & 1425.25 \\
Df & 171 \\
Sig. & 0.000 \\
\hline
\end{tabular}

The communality value decides whether a variable is to be included or not in the factor analysis; any value above 0.5 is considered to be ideal but certain variables with low communality value (i.e., $<0.5$ ) are also taken into consideration. Table 7 (communalities) shows the communality value of different variables of the study. Here, we can see that the communality value of all the variables majorly lies above the said value of 0.5 , therefore, all these factors are included in the factor analysis.

Table 4. Communalities

\begin{tabular}{lcr}
\hline & Initial & Extraction \\
\hline Years of association with the same bank & 1.000 & .542 \\
Availing all services from the same bank & 1.000 & .528 \\
Recommending your bank to other & 1.000 & .605 \\
Employee knowledgeably resolve queries & 1.000 & .550 \\
Employee gives individual attention & 1.000 & .479 \\
Enough operating branches in the city & 1.000 & .598 \\
Modern - Looking Equipment (Cash Deposit machine, Passbook Kiosk, fast ICT & 1.000 & .660 \\
facilities etc.) & & \\
Visually appealing and spacious interior and exterior of the bank & 1.000 & .545 \\
& & \\
Employees are professionally dressed & 1.000 & .545 \\
Safety in doing mobile/internet banking transactions & 1.000 & .199 \\
Safety in every transaction with the bank (account maintenance, cash transfer, & 1.000 & .614 \\
withdrawals and deposits etc.) & & \\
Speedy service provided by the bank & 1.000 & .634 \\
Grievance redressal procedure & 1.000 & .740 \\
Staff handles all problems in a very responsive manner & 1.000 & .670 \\
Staff is always willing to solve customer problems & 1.000 & .713 \\
Banking experience as far as charges for services are concerned & 1.000 & .640 \\
& & \\
Level of service quality & 1.000 & .827
\end{tabular}


Mobile/internet banking menu in Bank's application

* Extraction method: principal component analysis

When we look at the cumulative percentage of total variance explained, the acceptable range according to some researchers must be above $50 \%$ while some other criteria say that it should be between $70 \%-80 \%$. In this study, as shown in Table 8 (total variance explained) the cumulative $\%$ is $60.429 \%$.

The Table 9 (component matrix) and Table 10 (rotated component matrix) are given, to facilitate understanding of the distribution of the variance after the varimax rotation.

Table 8. Total Variance explained

\begin{tabular}{|c|c|c|c|c|c|c|c|c|c|}
\hline \multirow[t]{2}{*}{ Component } & \multirow[t]{2}{*}{ Total } & $\begin{array}{c}\text { Initial } \\
\text { Eigenvalues }\end{array}$ & $\begin{array}{c}\text { Extraction } \\
\text { Sums of } \\
\text { Squared } \\
\text { Loadings }\end{array}$ & \multicolumn{6}{|c|}{ Rotation Sums of Squared Loadings } \\
\hline & & $\begin{array}{c}\% \text { of } \\
\text { Variance }\end{array}$ & Cumulative \% & Total & $\begin{array}{c}\% \text { of } \\
\text { Variance }\end{array}$ & Cumulative \% & Total & $\begin{array}{c}\% \text { of } \\
\text { Variance }\end{array}$ & Cumulative \% \\
\hline 1 & 5.988 & 31.516 & 31.516 & 5.998 & 31.516 & 31.516 & 4.903 & 25.806 & 25.806 \\
\hline 2 & 1.690 & 8.896 & 40.412 & 1.690 & 8.896 & 40.412 & 2.257 & 11.880 & 37.686 \\
\hline 3 & 1.484 & 7.812 & 48.224 & 1.484 & 7.812 & 48.224 & 1.826 & 9.609 & 47.295 \\
\hline 4 & 1.253 & 6.594 & 54.818 & 1.253 & 6.594 & 54.818 & 1.296 & 6.820 & 54.115 \\
\hline 5 & 1.066 & 5.611 & 60.429 & 1.066 & 5.611 & 60.429 & 1.200 & 6.313 & 60.429 \\
\hline 6 & .996 & 5.241 & 65.669 & & & & & & \\
\hline 7 & .930 & 4.897 & 70.567 & & & & & & \\
\hline 8 & .829 & 4.364 & 74.931 & & & & & & \\
\hline 9 & 680 & 3.582 & 78.513 & & & & & & \\
\hline 10 & .665 & 3.497 & 82.010 & & & & & & \\
\hline 11 & .592 & 3.117 & 85.127 & & & & & & \\
\hline 12 & .486 & 2.560 & 87.687 & & & & & & \\
\hline 13 & .476 & 2.503 & 90.190 & & & & & & \\
\hline 14 & .446 & 2.347 & 92.537 & & & & & & \\
\hline 15 & .410 & 2.157 & 94.694 & & & & & & \\
\hline 16 & .341 & 1.793 & 96.487 & & & & & & \\
\hline 17 & .296 & 1.559 & 98.047 & & & & & & \\
\hline 18 & .213 & 1.121 & 99.168 & & & & & & \\
\hline 19 & .158 & .832 & 100.00 & & & & & & \\
\hline
\end{tabular}

Note: Extraction Method: Principal Component Analysis

Table 9. Component matrix 


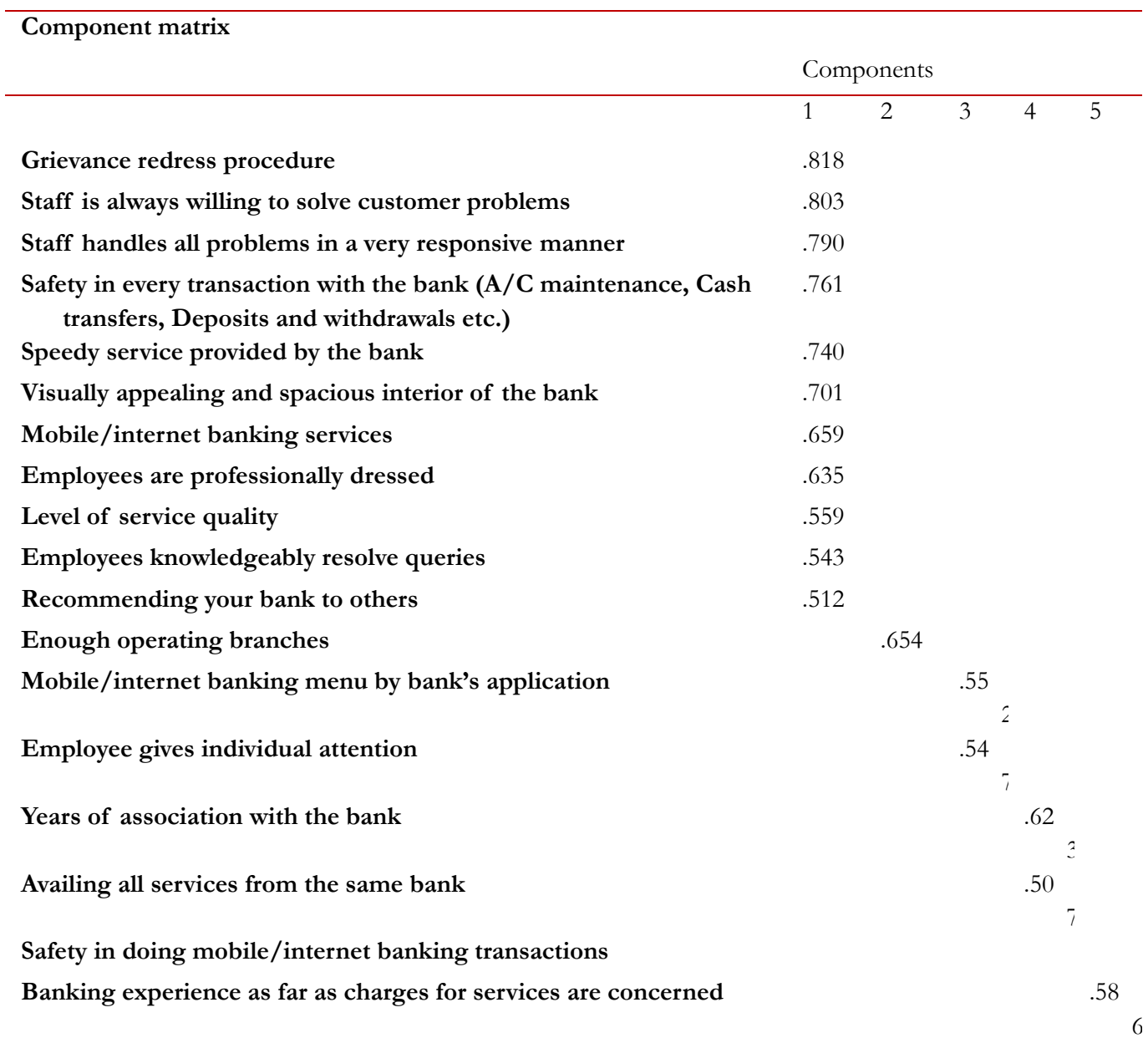

Modern-looking equipment (Passbook kiosk, cash deposit machine etc.)

*Extraction method: principal concept analysis

a. .5 components extracted 
Table 10. Rotated Component Matrix

Rotated component matrix

Components

$\begin{array}{lllll}1 & 2 & 3 & 4 & 5\end{array}$

Grievance redress procedure

832

Staff is always willing to solve customer problems

Staff handles all problems in a very responsive manner

Safety in every transaction with the bank (a/c maintenance, cash transfers, deposits and withdrawals etc.)

Speedy service provided by the bank

Visually appealing and spacious interior of the bank

Mobile/ internet banking services

Employees are professionally dressed

Level of service quality

Employees knowledgeably resolve queries

Recommending your bank to others

Enough operating branches

Mobile/internet banking menu by bank's application

Employee gives individual attention

Years of association with the bank

Availing all services from the same bank

Safety in doing mobile/ internet banking transactions

Banking experience as far as charges for services are concerned

Modern - looking equipment (passbook kiosk, cash deposit machine etc.)

Note: Extraction method: Principal Concept Analysis

a. .5 components extracted

\section{Chi-square test}

The chi-square test is used to check the relatedness of the two categorical variables in the study. It is a nonparametric test that shows whether there exists an association between them or not. For this purpose, the calculation of crosstabs on SPSS has been done between a few factors of customer loyalty and customer satisfaction. 
Years of association with the same bank and mobile/ internet banking services offered by the bank. When we look at the chi-square test of years of association with the same bank and mobile/internet banking services offered by the bank in Table 11 (Chi-Square test for years of association with the same bank and mobile/internet banking services offered by the bank), where years of association with the same bank depicts the "customer satisfaction" and the mobile/internet banking services offered by the bank shows "service quality" attribute, the chi-square statistic is 57.17 . The p-value appears to be 0.489 which is greater than the standard alpha value of 0.50 , so in this case, we will accept the null hypothesis (H0), that there is a significant relationship between service quality and customer satisfaction.

Table 5. Chi-square test for years of association with the same bank and mobile/internet banking services offered by the bank

\begin{tabular}{lcccc}
\hline & \multicolumn{3}{c}{ Chi-square tests } \\
\cline { 2 - 4 } & Value & df & Asymptotic Significance (2-sided) \\
\hline Pearson chi-square & $57.171^{\text {a }}$ & 57 & .569 \\
Likelihood ratio & 70.947 & 57 & .61 \\
Linear-by-linear association & .220 & 1 & .639 \\
N of valid cases & 200 & & \\
\hline $\begin{array}{l}\text { Not: } 70 \text { cells }(87.5 \%) \\
\text { count is } .17\end{array}$
\end{tabular}

\begin{tabular}{|c|c|c|c|c|c|}
\hline & & \multicolumn{4}{|c|}{ Symmetric Measure } \\
\hline & & Value & $\begin{array}{c}\text { Asymptotic } \\
\text { standard } \\
\text { error }^{\mathrm{a}} \\
\end{array}$ & $\begin{array}{c}\text { Approximat } \\
\text { e } \\
\mathbf{T}^{\mathrm{b}} \\
\end{array}$ & $\begin{array}{l}\text { Approximate } \\
\text { significance }\end{array}$ \\
\hline \multirow[t]{2}{*}{ Nominal value } & Phi & .535 & & & .569 \\
\hline & Cramer's V & .309 & & & .569 \\
\hline $\begin{array}{r}\text { Internal by } \\
\text { internal }\end{array}$ & Pearson's R & -.033 & .072 & -.468 & $.640^{c}$ \\
\hline \multirow{2}{*}{$\begin{array}{l}\text { Ordinal by } \\
\text { ordinal } \\
\mathbf{N} \text { of valid cases }\end{array}$} & $\begin{array}{l}\text { Spearman } \\
\text { Correlation }\end{array}$ & -.007 & .071 & -.101 & $.919 \mathrm{c}$ \\
\hline & & 200 & & & \\
\hline \multicolumn{6}{|c|}{ a. Not assuming the null hypothesis } \\
\hline \multicolumn{6}{|c|}{ b. Using the asymptotic standard error assuming the null hypothesis } \\
\hline
\end{tabular}

Years of association with the same bank and level of service quality. 
According to Table 12 (Chi-square test for years of association with the same bank and level of service quality), where years of association with the same bank depicts the "customer satisfaction", the chi-square statistic is 7.496 . The p-value appears to be 0.923 which is greater than the standard alpha value of 0.50 , so in this case we will accept the null hypothesis ( $\mathrm{H} 0)$, that there is a significant relationship between service quality and customer satisfaction.

Table 12. Chi-square test for Years of Association with the same Bank and Level of

\begin{tabular}{lccc}
\multicolumn{4}{c}{ Service Quality } \\
\hline \multicolumn{1}{c}{ Chi-square tests } & \\
\cline { 2 - 4 } & Value & df & $\begin{array}{l}\text { Asymptotic } \\
\text { significance } \\
\text { (2-sided) }\end{array}$ \\
\hline Pearson chi-square & $7.496^{\mathrm{a}}$ & 12 & .823 \\
Likelihood ratio & 9.518 & 12 & .658 \\
Linear-by-Linear Association & .000 & 1 & .994 \\
N of valid cases & 200 & & \\
\hline Note: 8 cells (40.0\%) have expected count less than 5. The minimum expected \\
count is .51
\end{tabular}

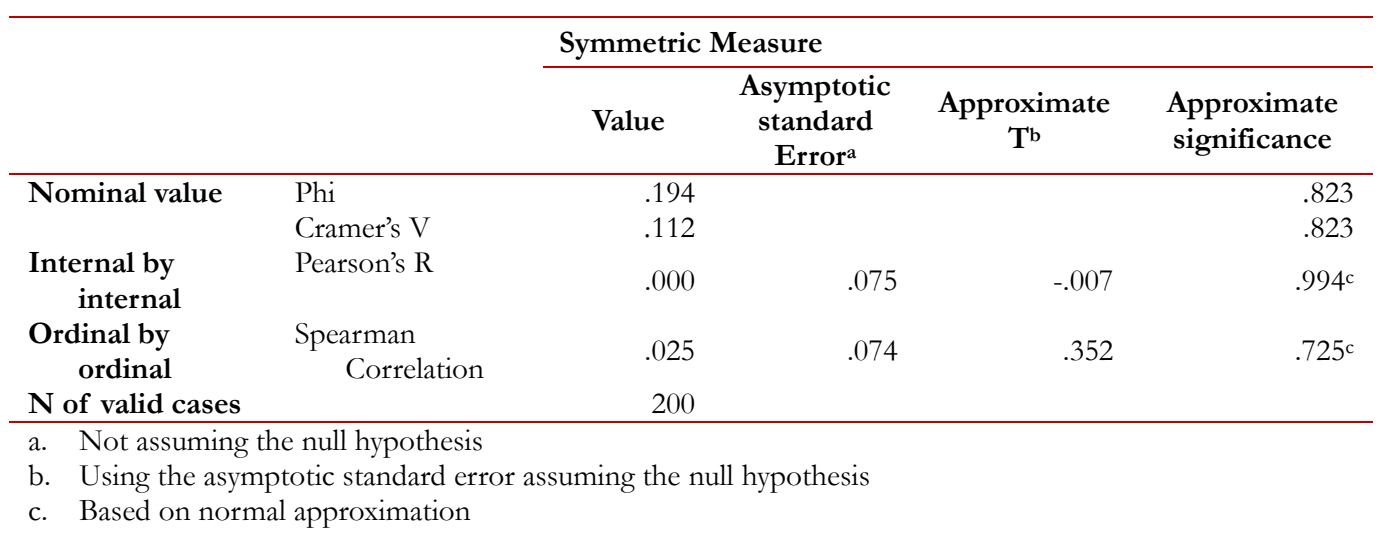

Availing all the services from the same bank and mobile/ internet banking menu provided by bank's application.

Let us look at the chi-square test of availing all the services from the same bank and bank and mobile/ internet banking menu provided by bank's application in Table 13 (Chi-square test for availing all the services from the same bank and mobile/internet banking menu provided by bank's application). The chi-square statistic is 18.742 . The $\mathrm{p}$-value appears to be 0.539 which is greater than the standard alpha value of 0.50 , so in this case, we will accept 
the null hypothesis (H0), that there is a significant relationship between service quality and customer satisfaction.

Table 13. Chi-square test for availing all the services from the same bank and mobile/internet banking menu provided by bank's application.

\begin{tabular}{lcrr}
\hline \multicolumn{3}{c}{ Chi-square tests } \\
\cline { 2 - 4 } & Value & df & $\begin{array}{c}\text { Asymptotic } \\
\text { significance } \\
\text { (2-sided) }\end{array}$ \\
\hline Pearson chi-square & $18.742^{\mathrm{a}}$ & 20 & .539 \\
Likelihood ratio & 21.890 & 20 & .347 \\
Linear-by-linear association & 1.290 & 1 & .256 \\
N of valid cases & 200 & & \\
\hline Note: 31 cells (73.8\%) have expected count less than 5. The minimum \\
$\quad$ expected count is .31
\end{tabular}

\begin{tabular}{|c|c|c|c|c|c|}
\hline & & \multicolumn{4}{|c|}{ Symmetric measure } \\
\hline & & Value & $\begin{array}{l}\text { Asymptotic } \\
\text { standard } \\
\text { error }^{\mathrm{a}}\end{array}$ & $\begin{array}{c}\text { Approximate } \\
\mathbf{T}^{\mathrm{b}}\end{array}$ & $\begin{array}{l}\text { Approximate } \\
\text { significance }\end{array}$ \\
\hline \multirow[t]{2}{*}{ Nominal value } & Phi & .306 & & & .539 \\
\hline & Cramer's V & .306 & & & .539 \\
\hline $\begin{array}{l}\text { Internal by } \\
\text { internal }\end{array}$ & Pearson's R & -.081 & .073 & -1.137 & .257 \\
\hline $\begin{array}{l}\text { Ordinal by } \\
\text { ordinal }\end{array}$ & $\begin{array}{l}\text { Spearman } \\
\text { Correlation }\end{array}$ & -.071 & .072 & -1.008 & $.315^{c}$ \\
\hline $\mathbf{N}$ of valid cases & & 200 & & & \\
\hline
\end{tabular}

a. Not assuming the null hypothesis

b. Using the asymptotic standard error assuming the null hypothesis

c. Based on normal approximation

Availing all the services from the same bank and level of service quality.

When we look at the chi-square test of Availing all the services from the same bank and level of service quality in Table 14 (chi-square test for availing all the services from the same bank and level of service quality), where availing all the services from the same bank depicts the "customer satisfaction", the chi-square statistic is 10.559 . The p-value appears to be 0.938 which is greater than the standard alpha value of 0.50 , so in this case we will accept the null hypothesis $(\mathrm{H} 0)$, that there is a significant relationship between service quality and customer satisfaction. 
Table 14. Chi-square test for availing all the services from the same bank and level of service quality

\begin{tabular}{lrrr}
\hline \multicolumn{2}{c}{ Chi-square tests } & & \\
\cline { 2 - 4 } & Value & df & $\begin{array}{c}\text { Asymptotic } \\
\text { Significance } \\
\text { (2-sided) }\end{array}$ \\
\hline Pearson Chi-Square & $10.599^{a}$ & 19 & .938 \\
Likelihood Ratio & 12.661 & 19 & .855 \\
Linear-by-Linear Association & .032 & 1 & .858 \\
N of Valid Cases & 200 & & \\
\hline
\end{tabular}

Note: 28 cells $(70.0 \%)$ have expected count less than 5 . The minimum expected count is .31

\begin{tabular}{|c|c|c|c|c|c|}
\hline & & \multicolumn{4}{|c|}{ Symmetric measure } \\
\hline & & Value & $\begin{array}{c}\text { Asymptotic } \\
\text { standard } \\
\text { error }^{\mathrm{a}} \\
\end{array}$ & $\begin{array}{c}\text { Approximate } \\
\mathbf{T}^{\mathbf{b}}\end{array}$ & $\begin{array}{l}\text { Approximate } \\
\text { significance }\end{array}$ \\
\hline \multirow{2}{*}{ Nominal value } & Phi & .230 & & & .938 \\
\hline & Cramer's V & .230 & & & .938 \\
\hline $\begin{array}{c}\text { Internal } \\
\text { internal }\end{array}$ & Pearson's R & -.013 & .068 & .179 & $.858 \mathrm{c}$ \\
\hline $\begin{array}{c}\text { Ordinal } \\
\text { ordinal }\end{array}$ & $\begin{array}{l}\text { Spearman } \\
\text { Correlation }\end{array}$ & -.024 & .068 & .339 & $.735^{c}$ \\
\hline $\mathbf{N}$ of valid cases & & 200 & & & \\
\hline
\end{tabular}

a. Not assuming the null hypothesis

b. Using the asymptotic standard error assuming the null hypothesis

c. Based on normal approximation

\section{Correlation}

The correlation between customer loyalty (after computing all the variables) and customer Satisfaction is shown in Table 15 (correlation between customer loyalty and customer satisfaction).

We can see that the p-value is .106, which is greater than $(>) 0.05$. Hence, it provides strong evidence for the acceptance of the null hypothesis (H0), there is a significant relationship between customer satisfaction and the customer's loyalty towards their banks. Therefore, we retain the null hypothesis and reject the alternative hypothesis. 
Table 15. Correlation between customer loyalty and customer satisfaction

\begin{tabular}{llcr}
\hline & \multicolumn{2}{c}{ Correlation } \\
\cline { 3 - 4 } & & Customer loyalty & $\begin{array}{c}\text { Customer } \\
\text { satisfaction }\end{array}$ \\
\hline Customer loyalty & $\begin{array}{c}\text { Pearson } \\
\text { Correlation }\end{array}$ & 1 & -.114 \\
& Sig. (2-Tailed) & & .106 \\
& N & 200 & 200 \\
Customer & Pearson & & 1 \\
satisfaction & $\quad$ Correlation & -.114 & \\
& Sig. (2-Tailed) & .106 & 200 \\
\hline & N & 200 & \\
\hline
\end{tabular}

After conducting the data analysis using SPSS software, the descriptive analysis showed that there are no missing frequencies and the number of valid responses was 200. The skewness as per the descriptive statistics was 0.172 which is between -0.5 to 0.5 , hence the distribution is approximately symmetric. As per the reliability test, the Cronbach's alpha of the study was 0.870 where, the accepted range is $0.6-0.7$, whereas 0.8 and greater represents a very good level of internal consistency i.e., items are closely related as a group. The KMO of the study was 0.836 , it measures the proportion of variance in the variables of the study, which varies between 0 to 1 , and any value closer to 1 is better. The total variance after the analysis was $60.429 \%$, wherein the acceptable range according to some researchers must be above $50 \%$.

The chi-square test was performed to check the relatedness of the two categorical variables in the study, to decide whether to accept or reject the null hypothesis (H0): There is a significant relationship between customer satisfaction and service quality of private banks. After performing the chi-square test for years of association with the same bank and mobile/internet banking services offered by the bank was 0.569 . The years of association with the same bank and level of service quality the Pearson Chi-square test was 0.823 . Then comes availing all the services from the same bank and mobile/internet Banking menu provided by bank's application, the pearson chi-square test was 0.539 . After performing the chi-square test for availing all the services from the same bank and level of service quality was 0.938 .

We can see that the p-value in all 4 cases is greater than $(>) 0.50$. Hence, it provides strong evidence for the acceptance of the null hypothesis (H0), there is a significant relationship between customer satisfaction and the customer's loyalty towards their banks. 
Talking about the correlation of customer loyalty (after computing all the variables) and customer satisfaction to test the null hypothesis (H0): There is a significant relationship between customer satisfaction and the customer's loyalty towards their banks. The correlation calculated was 0.106 We can see that the p-value is .106, which is greater than $(>)$ 0.05. Hence, it provides a piece of strong evidence for the acceptance of the null hypothesis $(\mathrm{H} 0)$, there is a significant relationship between customer satisfaction and the customer's loyalty towards their banks.

Therefore, both the null hypothesis ( $\mathrm{H} 0$ ) have been retained and the alternative hypothesis has been rejected. The service quality in private banks were studied with the help of attributes; responsiveness, tangible attributes, reliability, assurance and empathy (SERQUAL model).

\section{RECOMMENDATION AND SUGGESTIONS}

Existing study aimed at studying the impact of Covid-19 pandemic on household consumption, earning and employment in India. As per the data collected and subsequent After considering various responses for the study and day-to-day experiences, we observe several examples relating to online transaction frauds, wherein especially the senior citizens are vulnerable to lose money as they are not well-versed with the online transactional systems. Here, the Customer service officers can assist them with the online transactions and also counsel them about the prevention against fraudulent phone calls, messages and spam links. So, a better security framework must be implemented to secure online transactions and prevent fraudulent fund transfers. A strong system, with a double security authentication, where you can see the details of the person to whom you're transferring funds to ensure transparency in the transaction must be implemented and practiced.

Customers having small and medium businesses, who deal with cash transactions on daily basis have to spend a lot of time standing in the queue at the teller counters for these transactions along with passbook printing. If cash deposit machines and Passbook Kiosk are installed at the bank branch/ATMs, it becomes convenient for both, the depositor and the banker in terms of time and human resource management. All the available machines and equipment in a bank branch must be in a functional condition, if not, their repair and mend should be the priority concern of the branch. 
To learn more and more about the cliental needs and rather than offering everything banks must try to provide what a customer requires. For this purpose, studying the customer needs basing on the given information such as the customer's occupation, family size, the standard of living, etc. is a significant way of offering a sales pitch. Therefore, appointing a customer relationship manager is the wisest decision, as the customer has a point-of-contact in case any difficulty arises, this will also create a goodwill of the bank amongst the customer. Lately, a new term for taking care of customers via the internet, e-CRM (Customer Relationship Management), is recently applied by some organizational and academic communities (Ragins and Greco, 2003). Banks must also pay attention in providing services in a prompt manner and ensuring quick grievance redressal procedures.

There is a significant need for enhancement of the financial awareness in the citizens. This can be done by making creative videos that connect your customers with the bank heartfully or visually appealing advertisements and tutorial videos/digital templates to make them learn about certain banking operations.

\section{CONCLUSION}

The main objective of this research was to identify the key factors influencing service quality, customer satisfaction, and customer loyalty in private banks of India. The Indian banking sector is the backbone of the Indian economy, which undoubtedly is emerging as one of the leading sectors in terms of technological advancements and customized products and services as per customer's needs. In a rapidly developing country like India, it becomes vital for all its citizens to be provided with adequate financial products and services to meet their growing demands. Throughout the analysis, the question that what customer wants has been answered. They are the personal attention and sense of reliability wherein they can trust their banks while carrying out certain transactions or availing different banking products.

The major limitation to the study was accomplished responses from a relatively smaller number of cities. The attempt of collecting 200 responses to the questionnaire, shared in the format of a Google form was successful. However, the majority of responses were predominantly from two cities; Indore and Mumbai Table 3 (Location of the respondents). The study would have been finer and more diversifiable if more participants from other cities would have taken an initiative to respond. Many such pieces of research 
have been previously conducted focusing on other American, African, European, and a few Asian countries, but only a limited amount of data is available when we talk about India. The major outcomes of the study are:

a) The SERVQUAL dimensions and attributes play a key role in measuring customer satisfaction in private banks.

b) There exists a significant relationship between customer satisfaction and service quality of private banks.

c) There exists a significant relationship between customer satisfaction and the customer's loyalty towards their banks.

This means that the various service quality attributes/dimensions (reliability, empathy, responsiveness, assurance, loyalty and, tangible attributes) are positively related to customer satisfaction. And a satisfied customer is likely to be loyal to the bank.

The private banks must retain their existing customers along with converting the new potential ones. With the emergence of fintech partnerships and the entry of payment banks, the survival of existing banks has been questionable. Technological advancements in the banking sector have proved to enhance the customer's convenience in banking operations. The Covid-19 pandemic had a silver lining as it slightly pushed the people towards digitization of payment habits. More and more people are now becoming comfortable in using digital banking platforms.

The study suggests that the components of the SERVQUAL model; reliability, empathy, responsiveness, assurance, tangible attributes and loyalty are of utmost importance to attract and retain customers and banks must give focus on these factors to enhance customer satisfaction, as a satisfied customer is likely to be loyal towards the bank. The private banks must retain their existing customers along with converting the new potential ones (Babakus and Gregory 1992). New customers are digitally savvy and are well-versed with digital banking platforms, but in the case of existing customers, still there is a substantial customer segment that is reluctant or unable to adopt digital platforms for banking operations. In such a scenario bank should come up with segment-specific strategies which are relevant to their customers. More transparency and prompt customer redressal can give more confidence to the customers. Individual need based products and customer services are also required along with the technological advancements in the banking sector to enhance the customer's experience in banking operations. The Covid-19 
pandemic had a silver lining as it slightly pushed the people towards digitization of payment habits. But, at the same time, it is limiting the home banking services, i.e., going door to door. The private banks have to take cognizance of this scenario and strategize for a happier and more satisfied customer base.

\section{REFERENCES}

Babakus, E. and W. Gregory. 1992. An empirical assessment of the SERVQUAL scale. Journal of Business Research 24 (3): 253-268.

Bakhtiar, M. and H. Waqarul. 2012. Customer satisfaction: A comparison of public and private banks of Pakistan. IOSR Journal of Business and Management 185: 515-523.

Hennayake, H. 2017. Impact of service quality on customer satisfaction of public sector commercial bank: A study on rural economic context. International Journal of Scientific and Research Publications 7 (2): 156-161.

John, B. M. 2017. Dynamics of service quality in the Indian banking sector. Indian Journal of Commerce and Management Studies 8 (1): 59-63.

Kumar, A. and D. Manjunath. 2012. Service quality impact on customer satisfaction - A study of ICICI Bank in Mysore City. International Journal of Engineering and Management Research 2 (4): 1-4.

Lam, R. and Burton, S. 2006. SME banking loyalty (and disloyalty): a qualitative study in Hong Kong. International Journal of Bank Marketing, 24 (1): 37-52.

Mishra, S. U. and K. K Sahoo. 2010. Service quality assessment in banking industry of India: A comparative study between public and private sectors. European Journal of Social Sciences.

Munusamy, J. and C. Shankar. 2010. Service quality delivery and its impact on customer satisfaction in the banking sector in Malaysia. Journal of Innovation, Management and Technology 1 (4): 398-404.

Parasuraman, A., V. Zeithaml, and L. Berry. 1985. A conceptual model of service quality and its implications for future research. The Journal of Marketing. Retrieved from https://www.toolshero.com/quality-management/servqual-model/.

Priyanath, H. and W. Anjalika. 2018. Effect of service quality on customer satisfaction: An empirical study of customers who have bank accounts in both public and private banks in Sri Lanka. International Journal of Marketing and Technology. 
Ragins, E. and A. Greco. 2003. Customer relationship management and e-business: More than a software solution. Review of Business 1 (1): 25-30.

Schiffman, L. and L. Kanuk. 2004. Consumer Behavior. New Jersey: Pearson Prentice Hall.

Srinivas, D. and P. Rao. 2018. Service quality in commercial banks: A study of public sector banks in Warangal District.

Sureshchandar, G., C. Rajendran, and R. Ananthraman. 2003. Customer perceptions of service quality in the banking sector of a developing economy: A criticle analysis. International Journal of Bank Marketing.

Tam, J. 2004. Customer satisfaction, service quality and perceived value: an integrative model. Journal of Marketing Management.

Uncles, M., G. Dowling, and K. Hammond. 2003. Customer loyalty and customer loyalty programs. Journal of Consumer Marketing.

Yeung, M., L. Ging, D. Sschumann, S. Gardial, and M. Bums. 1991. The standards issues in CS/D research: A historical perspective. Journal of Customer Satisfaction and Complaining Behaviour. 